\title{
Gender Differences in Mental Health and Beliefs about Covid-19 among Elderly Internet Users
}

\author{
Heloísa Gonçalves Ferreira ${ }^{1}$
}

\begin{abstract}
Older people's mental health is at risk during the Covid-19 pandemic. This study investigated gender differences in home isolation, beliefs about Covid-19 and mental health indicators among elderly internet users during the pandemic. A total of 384 older persons $(66.9 \%$ women and $30.1 \%$ men) answered an online survey devised to collect information on sociodemographic characteristics, beliefs/attitudes about Covid-19, depression (PHQ-2), loneliness (short version of the UCLA-BR), social support and resilience (the BRS). Older women showed poorer mental health indicators, were more likely to adhere to home isolation and believe in the effectiveness of this measure, and felt more self-confident to self-isolate at home. Stronger perceived vulnerability to Covid-19 and awareness of the gravity of the disease were related to poorer mental health indicators among women. Older women are a highrisk group for negative mental health outcomes during the pandemic and should therefore be a primary focus of actions to mitigate the effects of the pandemic on mental health.
\end{abstract}

Keywords: depression, loneliness, resilience (psychology), old age

\section{Saúde Mental e Crenças sobre Covid-19 em Idosas e Idosos Usuários da Internet}

\begin{abstract}
Resumo: A saúde mental de idosos encontra-se em risco durante pandemia de Covid-19. Este estudo teve como objetivo analisar diferenças de sexo com relação ao isolamento domiciliar, crenças sobre Covid-19 e indicadores de saúde mental em idosos usuários de internet durante a pandemia. A amostra foi composta por 384 idosos (66,9\% mulheres e 30,1\% homens) que responderam instrumentos online para aferir: dados sociodemográficos, crenças/atitudes sobre Covid-19, depressão (PHQ-2), solidão (versão curta da UCLA-BR), suporte social e resiliência (EBR). Idosas apresentaram piores índices de saúde mental, aderiram mais ao isolamento domiciliar, relataram acreditar mais na efetividade do isolamento e sentiram-se mais autoconfiantes em praticá-lo. Percepções mais fortes sobre vulnerabilidade e gravidade da doença apresentaram relações com piores índices de saúde mental para as idosas. Idosas compreendem grupo de risco para desfechos negativos em saúde mental na pandemia da Covid-19, devendo esse grupo ser foco prioritário para ações de mitigação dos efeitos da pandemia no âmbito da saúde mental.
\end{abstract}

Palavras-chave: depressão, solidão, resiliência (psicologia), velhice

\section{Salud Mental y Creencias sobre Covid-19 en Ancianos y Ancianas Usuarios de Internet}

\begin{abstract}
Resumen: La salud mental de los ancianos está en riesgo en la pandemia de la Covid-19. Este estudio tuvo como objetivo analizar las diferencias de género en relación con el aislamiento domiciliario, las creencias sobre el Covid-19 y los indicadores de salud mental en los ancianos, que son usuarios de Internet, durante la pandemia. Una muestra de 384 ancianos (66,9\% mujeres y 30,1\% hombres) respondieron cuestionarios online para medir: datos sociodemográficos, creencias y actitudes sobre Covid-19, depresión (PHQ-2), soledad (versión corta del UCLA-BR), apoyo social y resiliência (EBR). Las mujeres de edad avanzada presentaron los peores índices de salud mental, se adhirieron más al aislamiento en el hogar, informaron que creían más en la efectividad del aislamiento y se sentían más seguras de sí mismas al practicarlo. Las percepciones más fuertes de vulnerabilidad y gravedad de la enfermedad mostraron más relaciones significativas con los peores índices de salud mental para las ancianas. Las ancianas son un grupo de riesgo de resultados negativos para la salud mental en la pandemia de la Covid-19, y este grupo debería ser un enfoque prioritario para las acciones de mitigación de los efectos de la pandemia en la salud mental.
\end{abstract}

Palabras clave: depresión, soledad, resiliencia (psicologia), vejez

${ }^{1}$ Universidade do Estado do Rio de Janeiro, Rio de Janeiro-RJ, Brazil Correspondence address: Heloísa Gonçalves Ferreira. Universidade do Estado do Rio de Janeiro. Instituto de Psicologia. Departamento de Cognição e Desenvolvimento. Rua São Francisco Xavier, 524, Maracanã, Rio de Janeiro-RJ, Brazil. CEP 20.550-900. E-mail: helogf@gmail.com
There are still a number of aspects of the Covid-19 pandemic that are yet to be studied. The risk of dying from the disease increases with age, with the majority of deaths occurring in people aged over 60 years and increased risk 
among older people with chronic diseases (Lloyd-Sherlock, Ebrahim, Geffen, \& McKee, 2020). Older people are a highrisk group and should therefore receive special attention from authorities, health professionals and researchers engaged in the response to the pandemic.

The mental health of older people is particularly at risk during these historic times, because this population group is especially prone to loneliness, isolation and symptoms of depression (Armitage \& Nellums, 2020). Physical distancing prevention measures may aggravate this situation, as older people tend to have less available sources of social support (Lloyd-Sherlock et al., 2020). In addition, being in a Covid-19 risk group may be considered a risk factor for the mental health of this population group (Qiu et al., 2020).

People age differently depending on the influence of a combination of biological, psychological and sociocultural factors. Sex has been shown to be an important variable to be considered in the investigation and interpretation of different aging trajectories and outcomes (Campos, Ferreira, \& Vargas, 2015; Sousa, Lima, Cesar, \& Barros, 2018).

Studies have revealed gender differences in mental health within the context of the Covid-19 pandemic. For example, women show higher levels of anxiety, depression and stress compared to men in Brazil (Filgueiras \& Stults-Kolehmainen, 2020) and other countries (Qiu et al., 2020; Özdin \& Özdin, 2020). In Brazil, few studies have investigated gender differences in mental health within the context of the pandemic.

The most recent concept of mental health highlights an individual's capacity to cope with life's adversities in addition to mental illness (World Health Organization [WHO], 2013). Thus, besides negatives constructs like depression and loneliness, it is also important to investigate an individual's capacity and resources to deal with adverse situations, such as resilience and social support. In this direction, this study investigated gender differences in mental health among older people within the context of the Covid-19 pandemic, exploring both negative (depression and loneliness) and positive (resilience and social support) constructs.

In addition to mental health indicators, it is also important to examine older peoples' beliefs and attitudes towards to the pandemic, as patterns of behavior and beliefs have a significant influence on mental health (Borges \& Barletta, 2015). Understanding health beliefs and attitudes, particularly within the context of the pandemic, is useful for the development and implementation of actions aimed at promoting healthprotective behavior.

However, due to the barriers to holding face-to-face interviews imposed by the pandemic, most mental health surveys are currently online (Pierce et al., 2020). Although this is a quick and low-cost method that allows researchers to reach a wider audience, online surveys can often lead to bias, including the chance of selecting convenience samples that are not representative of the target population. On the other hand, online surveys can explore perspectives and generate quick information on a specific topic, providing initial insights on a particular problem (Pierce et al., 2020) and allowing us to keep the social distance to preserve older people's health.
Thus, we opted to investigate mental health indicators in elderly internet users in Brazil who are able to participate in online surveys to provide initial insights into the impact of the pandemic on the well-being of older people in Brazil.

This study therefore analyzed gender differences in home isolation, beliefs about Covid-19 and mental health indicators among elderly internet users during the pandemic. The study had the following specific objectives: (1) to verify gender differences in home isolation and beliefs about Covid-19 and mental health indicators (depression, loneliness, resilience, and social support) among older people; and (2) to explore the relationship between home isolation, beliefs about Covid-19 and mental health indicators (depression, loneliness, resilience, and social support) among older people.

\section{Method}

\section{Participants}

A total of 422 people accessed the online survey link, five of whom opted not to take part in the survey after reading the informed consent form. An additional 33 individuals stated that they were aged under 60 years and were therefore excluded from the sample. The final sample consisted of 384 individuals aged 60 years and over, $66.9 \%$ of whom were women and $33.1 \%$ men. Thus, the study inclusion criteria were: (1) individuals aged 60 years and over, (2) internet users, (3) individuals who accepted to participate in the study. The exclusion criteria were: (1) individuals aged under 60 years, and (2) individuals who did not complete the survey.

\section{Instruments}

Sociodemographic questionnaire. Questionnaire devised to collect information on sex, level of education, marital status, number of people living with the older person and other sociodemographic characteristics.

Home isolation. Assessed using the question "How many times have you left the house in the last 2 weeks?", with the following response options: "not at all", "between one and five times", "between six and 10 times", and "more than 10 times".

Beliefs about the coronavirus and home isolation. Questionnaire consisting of five questions on beliefs about Covid-19 and adherence to home isolation. The questionnaire was based on the Health Belief Model (HBM) developed by Rosenstock, Strecher and Becker (1988, 1994). The HBM assumes that there is a relationship between the adoption of patterns of health-protective behavior (in this case adherence to home isolation) and the following: (1) personal beliefs about important and necessary disease prevention measures and the recognition of the fact that adopting new behavioral patterns is effective in reducing the risk of disease; (2) perceived vulnerability to the disease and awareness of the gravity of the consequences of the disease; and (3) self-confidence to adopt health-protective behavior (Borges \& Barletta, 2015). The following five questions were devised based on the HBM 
assumptions: "How vulnerable do you feel to contracting Covid-19?"; "If you experienced Covid-19 symptoms, how severe do you think the consequences of the disease might be for you?"; "How much do you agree that home isolation can help slow the spread of Coronavirus?"; "How much do you agree that home isolation can help prevent you from contracting Covid-19?"; and "How capable of home isolating do you feel?". These questions were rated on a four-point Likert scale and obtained an internal consistency of 0.69 for the study sample.

Two-item version of the Patient Health Questionnaire (PHQ-2). Derived from the PHQ-9, the PHQ-2 screens for depression based on two questions that inquire about the degree to which an individual has experienced depressed mood and anhedonia over the past two weeks. The questionnaire is answered using a four-point Likert scale ranging from zero (not at all) to three (nearly every day). Scores above 3 indicate depression. The scale obtained a sensitivity of $75 \%$ and specificity of $89 \%$ (Chagas et al., 2011). The internal consistency of the scale in the present study was 0.73 .

$U C L A-B R$ (short version). Derived from the UCLA-BR, the Brazilian version of the UCLA-R (Russell, Peplau, \& Cutrona, 1980), which assesses feelings of loneliness in adults and older people (Barroso, Andrade, Midgett, \& Carvalho, 2016). The short version (Barroso, 2020a), consists of six items referring to affective and cognitive states of loneliness felt recently and rated on a scale ranging from 0 (never) to 3 (often). The scale showed good internal consistency for the study sample $(\alpha=0.82)$ and significant relations with depression (rho $=0.37 ; p<0.01)$, social support $(r h o=-0.48 ; p<0.01)$ and resilience $(r h o=-0.43 ; p<0.01)$. The score ranges from 0 to 18 without a cutoff point, where the higher the score the higher the level of perceived loneliness.

Perceived social support. Measured using four questions: "Would you say that you have many people to talk to when you feel alone?"; "Would it be easy to find people to help you with your chores if you were sick?"; "Do you have someone you can rely on when you need advice on how to deal with a problem?"; and "Do you have at least one person whose opinion you fully trust?". The questions were answered on a four-point Likert scale ranging from 1 ("not at all") to 4 ("always"). These questions were taken from the Original Research Protocol of the Fibra Study, which assessed perceived social support among older Brazilians (Neri \& Vieira, 2013), focusing specifically on socioemotional, instrumental, informative and affective support. The instrument obtained an internal consistency of 0.74 for this study. The score ranges from 4 to 16 , where the higher the score the higher the level of perceived social support.

The Brief Resilience Scale (BRS). Version adapted for use in Brazil (Barroso, 2020b) based on the original fiveitem version developed by Smith et al. (2008). The internal consistency of the scale for the present study was 0.81 . The study data revealed that the scale showed significant relations with depression ( $r h o=-0.44 ; p<0.01)$, social support $(r h o=0.27 ; p<0.01)$ and loneliness $(r h o=-0.43 ; p<0.01)$, indicating validity evidence based on relationships with external variables. The items are rated on a five-point Likert scale ranging from "strongly disagree" to "strongly agree". Scores range from 5 to 25 with no cutoff scores, where the higher the score, the higher the level of resilience.

\section{Procedure}

Data collection. The instrument items were organized in Google Forms. The invitation to participate in the study containing the link to the research protocol was posted on social media (email, WhatsApp, Facebook, Instagram, etc.), including the emails of various open universities for senior citizens, Facebook groups organized for older people, research groups and the social networks used by the researchers involved in the study. Individuals aged 60 years and over who volunteered to participate in the study accessed the link to answer the instruments after reading the informed consent form and choosing the option "I understand the nature of this study and agree to participate". Data collection took place between April and May 2020.

Data analysis. The data were analyzed using suitable descriptive (means, standard deviation, minimum and maximum values, frequencies etc.) and inferential (correlation analysis) statistics. The test for normality showed that the variables were not normally distributed. Correlation analysis was therefore performed using Spearman's correlation coefficient. We used the chi-square test to measure gender differences in sociodemographic variables. Gender differences in home isolation and beliefs about Covid-19 and mental health indicators were tested using one-way ANOVA with resampling (bootstrapping; 1000 resamples; 95\% confidence interval). Resampling was used to improve the reliability of the results and correct deviations from normality and the incompatibility of group sizes (Haukoos \& Lewis, 2005). The data were analyzed using Microsoft Excel and IBM SPSS Statistics 20.0. P-values of greater than or equal to 0.05 were considered significant.

\section{Ethical Considerations}

The study was conducted in accordance with the ethical norms and standards for research involving human subjects set out in Resolution No. 466 (12/12/2012) and Resolution No. $510(07 / 04 / 2016)$ and approved by the Universidade Estadual do Rio de Janeiro's Research Ethics Committee (Approval No. 3.989.464 - CAAE No. 30915820.2.0000.5259).

\section{Results}

The sociodemographic characteristics of the sample are shown in Table 1. Significant differences between sexes were found in the number of people living with the participants and presence of chronic diseases. More women lived alone and a higher percentage of men lived with more people. A significantly higher proportion of women reported having at least one chronic disease. No significant differences between men and women were found in age and level of education. 
Table 1

Sociodemographic characteristics of the sample

\begin{tabular}{|c|c|c|c|c|c|c|}
\hline \multirow[t]{2}{*}{ Variables } & & \multicolumn{2}{|c|}{$\begin{array}{c}\text { Women } \\
(N=257)\end{array}$} & \multicolumn{2}{|c|}{$\begin{array}{c}\text { Men } \\
(N=127) \\
\end{array}$} & \multirow[t]{2}{*}{ Chi-squared } \\
\hline & & $\%$ & $N$ & $\%$ & $N$ & \\
\hline \multirow[t]{3}{*}{ Age } & $60-70$ years & 79.8 & 205 & 78.7 & 100 & \multirow{3}{*}{.53} \\
\hline & $71-80$ years & 18.3 & 47 & 18.1 & 23 & \\
\hline & Over 80 years & 1.9 & 5 & 3.1 & 4 & \\
\hline \multirow[t]{3}{*}{ Years of schooling } & No schooling & 1.2 & 3 & 0 & 0 & \multirow{3}{*}{2.71} \\
\hline & Up to 12 years & 16.7 & 43 & 12.6 & 16 & \\
\hline & More than 12 years & 82.1 & 211 & 87.4 & 111 & \\
\hline \multirow{3}{*}{$\begin{array}{l}\text { Number of people living } \\
\text { with the older person }\end{array}$} & Lives alone & 28 & 72 & 10.2 & 13 & \multirow{3}{*}{$55.66^{*}$} \\
\hline & Between 1 and 3 people & 40.9 & 105 & 81.1 & 103 & \\
\hline & More than 3 people & 31.1 & 80 & 8.7 & 11 & \\
\hline \multirow[t]{2}{*}{ Chronic disease } & Yes & 54.9 & 141 & 44.1 & 56 & \multirow{2}{*}{$3.94 *$} \\
\hline & No & 45.1 & 116 & 55.9 & 71 & \\
\hline
\end{tabular}

Note: ${ }^{*} p<0.0$.

Table 2 shows the gender differences in beliefs about Covid-19, home isolation and mental health indicators. With regard to attitudes and beliefs about Covid-19, there were significant differences between the sexes in frequency of going out, the belief that isolation reduces the spread of the virus and feeling capable of self-isolate at home. In this regard, men reported going out more than women, were less likely to believe that isolation reduces the spread of the virus and felt less capable of self-isolate at home. With regard to mental health indicators, the findings reveal that men showed significantly lower rates of depression and loneliness and significantly higher rates of resilience.

Table 2

Gender differences in beliefs/attitudes about Covid-19 and mental health indicators among older people

\begin{tabular}{|c|c|c|c|c|}
\hline & & $\begin{array}{l}\text { Women } \\
(N=257)\end{array}$ & $\begin{array}{c}\text { Men } \\
(N=127)\end{array}$ & $\begin{array}{l}\text { Sample total } \\
\quad(N=384)\end{array}$ \\
\hline Frequency of going out & $\begin{array}{l}M \\
S D\end{array}$ & $\begin{array}{c}0.72 * \\
.66\end{array}$ & $\begin{array}{c}1.15^{*} \\
.81\end{array}$ & $\begin{array}{l}0.86 \\
0.74\end{array}$ \\
\hline Perceived vulnerability & $\begin{array}{l}M \\
S D\end{array}$ & $\begin{array}{l}1.77 \\
.95\end{array}$ & $\begin{array}{c}1.61 \\
.91\end{array}$ & $\begin{array}{l}1.72 \\
.94\end{array}$ \\
\hline Perceived gravity of the disease & $\begin{array}{l}M \\
S D\end{array}$ & $\begin{array}{l}2.1 \\
.89\end{array}$ & $\begin{array}{c}1.91 \\
.88\end{array}$ & $\begin{array}{l}2.04 \\
.89\end{array}$ \\
\hline Isolation reduces virus spread & $\begin{array}{l}M \\
S D\end{array}$ & $\begin{array}{c}2.81^{*} \\
.56\end{array}$ & $\begin{array}{c}2.52 * \\
.78\end{array}$ & $\begin{array}{l}2.71 \\
.65\end{array}$ \\
\hline Isolation prevents virus contraction & $\begin{array}{l}M \\
S D\end{array}$ & $\begin{array}{l}2.7 \\
.66\end{array}$ & $\begin{array}{c}2.59 \\
.68\end{array}$ & $\begin{array}{c}2.66 \\
.67\end{array}$ \\
\hline Self-confidence to home isolate & $\begin{array}{l}M \\
S D\end{array}$ & $\begin{array}{c}2.73^{*} \\
.58\end{array}$ & $\begin{array}{c}2.58^{*} \\
.64\end{array}$ & $\begin{array}{c}2.68 \\
.60\end{array}$ \\
\hline Resilience & $\begin{array}{l}M \\
S D\end{array}$ & $\begin{array}{c}18.11^{*} \\
4.18\end{array}$ & $\begin{array}{c}19.89^{*} \\
3.85\end{array}$ & $\begin{array}{l}18.7 \\
4.15\end{array}$ \\
\hline Social support & $\begin{array}{l}M \\
S D\end{array}$ & $\begin{array}{c}13.57 \\
2.39\end{array}$ & $\begin{array}{c}13.81 \\
2.25\end{array}$ & $\begin{array}{c}13.65 \\
2.35\end{array}$ \\
\hline Depression & $\begin{array}{l}M \\
S D\end{array}$ & $\begin{array}{c}1.58^{*} \\
1.51\end{array}$ & $\begin{array}{l}.74 * \\
1.17\end{array}$ & $\begin{array}{c}1.3 \\
1.46\end{array}$ \\
\hline Loneliness & $\begin{array}{l}M \\
S D\end{array}$ & $\begin{array}{c}5.54 * \\
4\end{array}$ & $\begin{array}{c}4.37^{*} \\
3.45\end{array}$ & $\begin{array}{l}5.15 \\
3.86\end{array}$ \\
\hline
\end{tabular}

Note: $*_{p}<0.05$. 
Tables 3 and Table 4 show the relations between beliefs/ attitudes about Covid-19 and mental health indicators among men and women, respectively. In general, the findings show that there were more significant relations between beliefs/ attitudes about Covid-19 and mental health indicators among women than men. Similar patterns were found between men and women for the relations between feeling capable of self-isolate at home and mental health indicators (resilience, social support and loneliness). The findings also show that there were more significant associations between perceived vulnerability and awareness of the gravity of the disease and mental health indicators among women. There was a significant relationship between social support and the belief that isolation reduces the spread of the disease among men.

Table 3

Relations between beliefs/attitudes about Covid-19 and mental health indicators among older men

\begin{tabular}{|c|c|c|c|c|}
\hline & Resilience & Social support & Depression & Loneliness \\
\hline Frequency of going out & .00 & -.11 & -.04 & .03 \\
\hline Perceived vulnerability & -.11 & .13 & $.20^{*}$ & .12 \\
\hline Perceived gravity of the disease & -.44 & .05 & .14 & .13 \\
\hline Isolation reduces virus spread & -.01 & $.21^{*}$ & .07 & -.01 \\
\hline Isolation prevents virus contraction & .04 & .14 & -.03 & -.06 \\
\hline Self-confidence to home isolate & $.23^{* *}$ & $.25^{* *}$ & -.13 & $-.21^{*}$ \\
\hline
\end{tabular}

Note: $* p<.05 ; * * p<.01$.

Table 4

Relations between beliefs/attitudes about Covid-19 and mental health indicators among older women

\begin{tabular}{lcccc}
\hline & Resilience & Social support & Depression & Loneliness \\
\hline Frequency of going out & .06 & -.07 & -.09 &. .05 \\
Perceived vulnerability & $-.22^{* *}$ & -.02 & $.21^{* *}$ & .10 \\
Perceived gravity of the disease & $-.22^{* *}$ & -.06 & $.25^{* *}$ & $.14^{*}$ \\
Isolation reduces virus spread & .03 & .05 & .05 & .07 \\
Isolation prevents virus contraction & -.03 & .07 & .07 & $.12^{*}$ \\
Self-confidence to home isolate & $.12^{*}$ & $.24^{* *}$ & -.06 & $-.13^{*}$ \\
\hline
\end{tabular}

Note: $* p<.05 ; * * p<.01$.

\section{Discussion}

This study examined gender differences in home isolation, beliefs about Covid-19 and mental health indicators among elderly internet users during the pandemic. The fact that the study was limited to older people with access to the internet has some implications that should to be considered when interpreting the results. For example, the sample cannot be considered representative of the general population of older people in Brazil as only a small proportion of older Brazilians use the internet. In this regard, the results of a populationbased study conducted by Sousa et al. (2018) showed that $21.7 \%$ of elderly Brazilians use the internet. The results of the present study therefore only serve as a basis for understanding the reality of this specific group of older people, which does not represent the majority of older people in Brazil.

The results point to gender differences in mental health, adherence to home isolation and beliefs about Covid-19. The women in our sample show higher rates of depression and loneliness and lower rates of resilience than men. This suggests that women are more vulnerable to mental health problems in times of pandemic, corroborating the findings of previous studies (Filgueiras \& Stults-Kolehmainen, 2020; Özdin \& Özdin, 2020; Qiu et al., 2020). With regard to sociodemographic characteristics, a significantly higher proportion of women reported living alone, suggesting that women have less access to social support in a domestic context than men. In addition, women were significantly more likely to have a chronic disease, suggesting that both the mental and physical health of these women is at risk, especially considering that older persons with chronic diseases are a high-risk group for Covid-19 (Lloyd-Sherlock et al., 2020).

One possible explanation for the poorer mental health indicators among women is the fact that even prior to the pandemic women were more likely to suffer domestic violence (Carpena, Costa, Martins-Silva, Xavier, \& Loret de Mola, 2020) and be overloaded with household chores and caregiving roles (Pinho \& Araújo, 2012), which has a negative effect on mental health. Within the context of the pandemic, it is likely that these differences were aggravated by home isolation, meaning that women have had to take on more tasks, in addition to the risk of being more vulnerable to domestic violence. Older women are therefore a high-risk group for negative mental health outcomes. 
Marques, Moraes, Hasselmann, Deslandes, and Reichenheim (2020) propose the following alternatives to prevent domestic violence against women during the pandemic: (1) Guarantee the provision of a 24/7 in-person or remote service for victims of domestic violence by competent bodies; (2) Guarantee speedy processing of complaints of domestic violence against women; (3) Reinforce advertising campaigns to raise awareness of domestic violence during the pandemic so that both victims and people close to them can act to avoid episodes of violence; (4) Provide support, counselling, social assistance, legal aid and healthcare to victims; (5) Help ensure that women in situations of violence practice social distancing in the company of other family members who do not pose a risk; and (6) the elaboration of a safe escape plan in extreme situations.

With regard to beliefs and attitudes about Covid-19, women were more likely to adhere to home isolation, believe in the effectiveness of this measure, and feel more capable of practice home isolation than men. In this regard, the data suggest that women were more likely to adhere to health-protective practices than men, corroborating the findings of Botton, Cúnico and Strey (2017) in a literature review about gender differences in access to health services and protective health behavior. Botton et al. (2017) point out that cultural factors may partially explain differences between men and women in adherence to protective health measures. Men are usually encouraged to adopt patriarchal values, meaning that health and self-care practices are seen to be inconsistent with masculinity and reinforcing stereotypes that suggest men should be strong, brave, independent and virile, which in turn may prevent them to adopt protective health measures. It is possible that these stereotypes are even more present in the older population, influencing older men's attitudes towards and beliefs about social distancing measures.

Although our findings suggest that women appear to be more cautious than men during the pandemic, stronger perceived vulnerability and awareness of the gravity of the disease were related to poorer mental health indicators (higher rates of depression and loneliness and lower rates of resilience) among women. Thus, while women tend to feel more vulnerable and are more aware of the gravity of the disease, they also show poorer mental health indicators. However, since correlation does not necessarily imply causation, we cannot confirm whether the fact that women feel more vulnerable and are more aware of the gravity of Covid-19 negatively affects their mental health. Future studies should take a more in-depth look at the nature of these relationships. However, these findings do suggest that the pandemic is having a greater effect on the mental health of women.

The findings regarding the relationships between mental health indicators and beliefs/attitudes about Covid-19 also show that there were more significant relations between these constructs among women, suggesting that the mental health of women is more influenced by beliefs about Covid- 9 than in men. Interventions aimed at promoting the mental health of older women in times of the Covid-19 pandemic should therefore take these aspects into consideration, particularly perceived vulnerability and awareness of the gravity of the disease.

The relations between being capable of self-isolate and mental health indicators (resilience, social support and loneliness) followed a similar pattern among both men and women, indicating that the more the elderly feel capable of self-isolate, the higher the levels of resilience and social support and the lower the level of loneliness. These findings suggest that the social component might be central to feeling capable of staying at home in times of pandemic among both men and women. This is because social support and social contact are a protective factor against feeling lonely, and when the elderly have more social support and feel less lonely, it might get easier to self-isolate at home. Interventions focused on helping older people to feel more capable of self-isolating should therefore consider that older people need to reorganize how they maintain their social contacts in order to preserve social interaction, while at the same time maintaining effective social support networks. For Armitage and Nellums (2020), examples of minor interventions to help older people to maintain social contact and provide sources of social support in times of pandemic include the use of online technologies, more frequent telephone contact with friends and family, the delivery of groceries and medications by voluntary services and online counselling.

The findings show that older people who were more resilient felt more capable of staying at home in times of pandemic. This is probably because they find it easier to adapt to adverse situations (Fontes \& Neri, 2015) and in turn adhere to protective health measures. Resilience is thus another key psychological component of interventions aimed at promoting adherence to protective health measures in times of pandemic such as home isolation.

With regard to the promotion of mental health in times of pandemic, Zanon, Dellazzana-Zanon, Wechsler, Fabretti, and Rocha (2020) suggest that positive psychology interventions focused on developing skills such as resilience, optimism, subjective well-being and gratefulness might be useful to mitigate the effects of isolation on mental health. In this regard, self-confidence to stay at home can be understood as a key component of positive psychology interventions, since spending more time at home can also provide benefits such as the chance to spend more time in one's own company and discover new personal projects and hobbies, as well as providing the opportunity of being closer to the family, strengthening bonds and doing pleasurable activities (Zanon et al., 2020). The adoption of a more positive perspective in relation to spending more time at home may help mitigate the negative effect of the pandemic on mental health.

This study provides a general overview of mental health and its relationship with home isolation and beliefs about Covid-19 among elderly internet users. Although our study sample is not representative of the general elderly population in Brazil, the data provide a valuable input to inform the development and implementation of actions aimed at protecting and promoting the mental health of specific groups at risk in during the pandemic, as appears to be the case with older women. 
The fact that we used a convenience sample made up of older people with access to the internet is an important limitation of the study. Our findings should thus not be generalized to the general older population in Brazil, since the sample is made up of people with better socioeconomic status, which also probably influenced the mental health profile and beliefs observed in the sample. Future studies should focus on seeking ways of accessing older people who do not use the internet in order to investigate questions pertinent to the physical and mental health of this population group. It would also be interesting to explore other mental health indicators such as anxiety, stress and the involvement in pleasant events among older people in the context of the pandemic.

From an overall perspective, this study showed gender differences in mental health indicators, indicating that women are more likely to suffer from depression and loneliness and have lower levels of resilience in the face of the Covid-19 pandemic. Our findings also show that there were relations between beliefs about Covid-19 and mental health, particularly among women, highlighting that interventions aimed at promoting mental health should take into account the particularities of this group and that older women should be the primary focus of health professionals, researchers and authorities when it comes to the implementation of measures to mitigate the effects of the pandemic on mental health.

\section{References}

Armitage, R., \& Nellums, L. B. (2020). COVID-19 and the consequences of isolating the elderly. Lancet Public Health, 5(5), e256. doi:10.1016/S2468-2667(20)30061-X

Barroso, S. M. (2020a). Versão Reduzida da Escala Brasileira de Solidão UCLA (UCLA-BR-R) [ Short Version of the Brazilian Loneliness Scale UCLA(UCLA-BR-R)] Relatório final de pesquisa apresentado para o Comitê de Ética em Pesquisa da Universidade Federal do Triângulo Mineiro. [Final research report submitted to the Research Ethics Committee of Federal University of Triângulo Mineiro] Uberaba, Minas Gerais. Relatório não publicado.

Barroso, S. M. (2020b). Adaptação e evidências de validade da Escala Breve de Resiliência - versão Brasileira [Adaptation and validity evidence of the Brazilian Version of the Brief Resilience Scale]. [Relatório final de pesquisa apresentado para o Comitê de Ética em Pesquisa da Universidade Federal do Triângulo Mineiro]. .[Final research report submitted to the Research Ethics Committee of Federal University of Triângulo Mineiro] Uberaba, Minas Gerais. Relatório não publicado.

Barroso, S. M., Andrade, V. S., Midgett, A. H., \& Carvalho, R. G. N. (2016). Evidências de validade da Escala Brasileira de Solidão UCLA [Evidence of validity of Brazilian UCLA Loneliness Scale]. Revista Brasileira de Psiquiatria, 65(1), 68-75. doi:10.1590/0047-2085000000105
Borges, L. M., \& Barletta, J. B. (2015). Teorias e modelos explicativos em prevenção e promoção da saúde orientados para o indivíduo e para a comunidade [Explanatory theories and models in prevention and health promotion oriented to the individual and the community]. In S. G. Murta, C. LeandroFrança, K. B. Santos, \& L. Polejack (Orgs.), Prevenção e promoção em saúde mental: Fundamentos, planejamento e estratégias de intervenção [Mental health prevention and promotion: Fundamentals, planning and intervention strategies] (pp. 113-149). Novo Hamburgo, RS: Sinopsys.

Botton, A., Cúnico, S. D., \& Strey, M. N. (2017). Diferenças de gênero no acesso aos serviços de saúde: Problematizações necessárias [Gender differences in the access to health services: Necesssary problematization]. Mudanças Psicologia da Saúde, 25(1), 67-72. doi:10.15603/21761019/mud.v25n1p67-72

Campos, A. C. V., Ferreira, E. F., \& Vargas, A. M. D. (2015). Determinantes do envelhecimento ativo segundo a qualidade de vida e gênero [Determinants of active aging according to quality of life and gender]. Ciência \& Saúde Coletiva, 20(7), 2221-2237. doi:10.1590/1413-81232015207.14072014

Carpena, M. X., Costa, F. S., Martins-Silva, T., Xavier, M. O., \& Loret de Mola, C. (2020). Why Brazilian women suffer more from depression and suicidal ideation: A mediation analysis of the role of violence. Brazilian Journal of Psychiatry, 42(5), 469-474. doi:10.1590/1516-4446-2019-0572

Chagas, M. H. N., Crippa, J. A., Loureiro, S. R., Hallak, J. E., Meneses-Gaya, C. D., Machado-de-Sousa, J. P., Rodrigues, G. R., Filho A. S., Sanches, R. F., \& Tumas, V. (2011). Validity of the PHQ-2 for the screening of major depression in Parkinson's disease: Two questions and one important answer. Aging \& Mental Health, 15(7), 838-843. doi:10.1080/13607863.2011.569482

Filgueiras, A., \& Stults-Kolehmainen, M. (2020). The relationship between behavioural and psychosocial factors among Brazilians in quarantine due to COVID-19. The Lancet. doi:10.2139/ssrn.3566245

Fontes, A. P., \& Neri, A. L. (2015). Resilience in aging: Literature review. Ciência \& Saúde Coletiva, 20(5), 1475-1495. doi:10.1590/1413-81232015205.00502014

Haukoos, J. S., \& Lewis, R. J. (2005). Advanced statistics: Bootstrapping confidence intervals for statistics with "difficult" distributions. Academic Emergency Medicine, 12(4), 360-365. doi:10.1197/j.aem.2004.11.018

Lloyd-Sherlock, P., Ebrahim, S., Geffen, L., \& McKee, M. (2020). Bearing the brunt of covid-19: Older people in low and middle income countries. BMJ, 368, m1052. doi:10.1136/bmj.m1052

Marques, E. S., Moraes, C. L., Hasselmann, M. H., Deslandes, S. F., \& Reichenheim, M. E. (2020). Violence against women, children, and adolescentes during the COVID-19 pandemic: Overview, contributing factors, and mitigating measures. Cadernos de Saúde Pública, 36(4), e00074420. doi:10.1590/0102-311x00074420 
Neri, A. L., \& Vieira, L. A. M. (2013). Envolvimento social e suporte social percebido na velhice [Social involvement and perceived social support in old age]. Revista Brasileira de Geriatria e Gerontologia, 16(3), 419-432. doi:10.1590/ S1809-98232013000300002

Özdin, S., \& Özdin, S. B. (2020). Levels and predictors of anxiety, depression and health anxiety during COVID-19 pandemic in Turkish society: The importance of gender. International Journal of Social Psychiatry, 66(5), 504-511. doi:10.1177/0020764020927051

Pierce, M., McManus, S., Jessop, C., John, A., Hotopf, M., Ford, T., ... Abel, K. M. (2020). Says who? The significance of sampling in mental health surveys during COVID-19. Lancet Psychiatry, 7(7), 567-568. doi:10.1016/S22150366(20)30237-6

Pinho, P. S., \& Araújo, T. M. (2012). Association between housework overload and common mental disorders in women. Revista Brasileira de Epidemiologia, 15(3), 560-572. doi:10.1590/S1415-790X2012000300010

Qiu, J., Shen, B., Zhao, M., Wang, Z., Xie, B., \& Xu, Y. (2020). A nationwide survey of psychological distress among Chinese people in the COVID-19 epidemic: Implications and policy recommendations. General Psychiatry, 33(2), e100213. doi:10.1136/gpsych-2020-100213

Rosenstock, I. M., Strecher, V. J., \& Becker, M. H. (1988). Social learning theory and the Health Belief Model. Health Education Quarterly, 15(2), 175-183. doi:10.1177/109019818801500203

Rosenstock, I. M., Strecher, V. J., \& Becker, M. H. (1994). The Health Belief Model and the HIV risk behavior change. In R. J. DiClemente \& J. L. Peterson (Eds.), Preventing AIDS: Theories and methods of behavioral interventions (pp. 5-24). New York, NY: Plenum.

Russell, D., Peplau, L. A., \& Cutrona, C. E. (1980). The revised UCLA Loneliness Scale: Concurrent and discriminant validity evidence. Journal of Personality and Social Psychology, 39(3), 472-480. doi:10.1037/0022-3514.39.3.472

Smith, B. W., Dalen, J., Wiggins, K., Tooley, E., Christopher, P., \& Bernard, J. (2008). The Brief Resilience Scale: Assessing the ability to bounce back. International Journal of Behavioral Medicine, 15(3), 194-200. doi:10.1080/10705500802222972

Sousa, N. F. S., Lima, M. G., Cesar, C. L. G., \& Barros, M. B. A. (2018). Active aging: Prevalence and gender and age differences in a population-based study. Cadernos de Saúde Pública, 34(11), e00173317. doi:10.1590/0102-311x00173317

World Health Organization. (2013). Mental health action plan 2013-2020. Geneva, Switzerland: Author. Retrieved from https://apps.who.int/iris/rest/bitstreams/424776/retrieve

Zanon, C., Dellazzana-Zanon, L. L., Wechsler, S. M., Fabretti, R. R., \& Rocha, K. N. (2020). COVID-19: Implicações e aplicações da Psicologia Positiva em tempos de pandemia [COVID-19: Implications and applications of Positive Psychology in times of pandemic]. Estudos de Psicologia (Campinas), 37, e200072. doi:10.1590/1982-0275202037e200072
Heloisa Gonçalves Ferreira is a professor at the Universidade do Estado do Rio de Janeiro, Rio de Janeiro-RJ, Brazil.

Authors' contributions:

The author was responsible for study conception and design, data analysis and interpretation, the drafting of this manuscript, and the approval of the final version. The author assumes public responsibility for the content of this manuscript.

Associate editor:

Vanessa Barbosa Romera Leme

Received: Aug. 06, 2020

1st Revision: Oct. 13, 2020

Approved: Oct. 27, 2020
How to cite this article:

Ferreira, H. G. (2021). Gender differences in mental health and beliefs about Covid-19 among elderly internet users. Paidéia (Ribeirão Preto), 31, e3110.doi:https://doi.org/10.1590/1982-4327e3110 